\title{
Antifungal activity and action mechanisms of yeasts isolates from citrus against Penicillium italicum
}

\author{
Tatiane da Cunha ${ }^{\mathrm{a}}$, Luriany Pompeo Ferraz ${ }^{\mathrm{a}}$, Pitt Paul Wehr ${ }^{\mathrm{b}}$, Katia Cristina Kupper ${ }^{\mathrm{a}, \mathrm{c}, *}$ \\ a Universidade Estadual Paulista "Júlio de Mesquita Filho"/UNESP, CEP 14884-900 Jaboticabal, SP, Brazil \\ ${ }^{\mathrm{b}}$ Universidade Federal de São Carlos/UFSCar, CEP 13600-970 Araras, SP, Brazil \\ ${ }^{\mathrm{c}}$ Centro de Citricultura Sylvio Moreira, Instituto Agronômico, Rod. Anhanguera, Km 158, CEP 13490-970 Cordeirópolis, SP, Brazil
}

\section{A R T I C L E I N F O}

\section{Keywords:}

Blue mold

Citrus sinensis

Hydrolytic enzymes

'Killer' factor

Yeast antagonists

\begin{abstract}
A B S T R A C T
Penicillium italicum (Blue mold) is a major postharvest disease of citrus. An alternative to controlling the disease is through the use of yeasts. The purpose of the present study was to screen effective yeast antagonists against $P$. italicum, isolated from soil, leaves, flowers, and citrus fruits, to assess the action mechanisms of the yeast isolates that were demonstrated to be effective for biocontrol, and to identify the most effective yeast isolates for the biocontrol of blue mold. The in vitro assays showed that six yeast strains inhibited up to $90 \%$ of the pathogen's mycelial growth. In vivo assays, evaluating the incidence of blue mold on sweet oranges, the strains ACBL-04, ACBL-05, ACBL-10 and ACBL-11 were effective, demonstrating the potential for the blue mold control when preventively applied, whereas the ACBL-08 strain showed a high potential to preventive and curative applications. Additional studies on the modes of action of these yeast strains showed that most of the evaluated yeast strains did not produce antifungal substances, in sufficient quantities to inhibit the pathogen growth. Competition for nutrients was not a biocontrol strategy used by the yeast strains. The 'killer' activity might be the main action mechanism involved in $P$. italicum biocontrol. This study indicated that the multiple modes of action against the pathogen presented by yeasts may explain why these strains provided $P$. italicum control under in vitro and in vivo conditions. However, further studies in future might be able to elucidate the 'killer' activity and its interaction with pathogen cells and the bioproduct production using Candida stellimalicola strains for control postharvest diseases.
\end{abstract}

\section{Introduction}

Citrus spp. is one of the most cultivated fruits worldwide. In 2015, the world citrus production was around 121 million tons (Strano et al., 2017), which was $20.0 \%$ of total fruit production. Harvested fruits are usually stored before they reach the market for fresh consumption. During this period, approximately $20 \%$ of harvested fruits undergo decay during postharvest storage (Fu et al., 2014; Hodges et al., 2011; Tao et al., 2014). It has been reported that Penicillium italicum Wehmer cause blue mold, one of the most economically important citrus postharvest disease (García-Cela et al., 2014; Hernández-Montiel et al., 2010; Tian et al., 2011; Zhang et al., 2005). The fruits are infected through wounds, caused during harvesting and transportation, leading to quick losses in the yield and in the fruits quality (Lahlali et al., 2006; Palou et al., 2002).

Currently, the blue mold is primarily controlled by the synthetic fungicide applications, such as thiabendazole and imazalil (Sun et al., 2013). However, problems related to the development of pathogen resistance to many site-specific fungicides and to the potentially harmful effects on human safety and environment have stimulated researches related to alternative methods for disease control in postharvest (Lahlali et al., 2014; Palou et al., 2002; Zhou et al., 2014).

Biological control using microbial agents is considered to be a viable alternative to the use of synthetic fungicides. Among microbial agents, yeasts have several properties that make them ideal antagonists, including the ability to survive in adverse environmental conditions, having few nutritional requirements and being amenable to formulation with a long shelf-life. Recent researches showed the use of yeasts in the control of fungal diseases in postharvest (Ferraz et al., 2016; J. Liu et al., 2013; Liu et al., 2014; Moretto et al., 2014; Platania et al., 2012).

Understanding the action mechanism of antagonistic microorganisms is essential for using them in a safe and effective manner. The biocontrol activity exhibited by yeasts used to manage postharvest diseases has been reported to be associated with their ability to compete with fungal pathogens for nutrients and space, to adhere to host and pathogen tissues, by the production of exo- $\beta$-1,3-glucanase and

\footnotetext{
* Corresponding author at: Centro de Citricultura Sylvio Moreira, Instituto Agronômico, Rod. Anhanguera, Km 158, CEP 13490-970 Cordeirópolis, SP, Brazil.

E-mail address: katia@ccsm.br (K.C. Kupper).
} 
chitinase, to induce host resistance, to secrete organic acids and lytic enzymes, including some that produce 'killer' toxins (J. Liu et al., 2013; Parafati et al., 2016; Spadaro and Droby, 2016).

In this context, the objectives of this work were: (1) to select yeast isolates obtained from citrus crops with potential to Penicillium italicum control, (2) to assess the mechanisms of action of the yeast isolates that showed potential for biocontrol and, (3) to identify the most effective yeast isolates for the biocontrol of $P$. italicum. These results could be contributing for yeast-based-products as an alternative against fruits post-harvest pathogens management.

\section{Material and methods}

\subsection{Pathogen}

The pathogen ( $P$. italicum) used in this study was obtained from microorganism's collection of the APTA Center Citrus "Sylvio Moreira"/ IAC, Cordeirópolis, São Paulo State, Brazil.

\subsection{Yeasts isolation}

The yeast biological control agents (ACBL) were isolated from leaves, flowers, fruits, and soils. They were obtained from 14 citrus producing regions in the São Paulo State, Brazil. The yeast isolation was carried out according to Azeredo et al. (1998) and Ferraz et al. (2016), using the decimal dilution technique, in which a $0.85 \%$ saline solution was used for the soil, and a sterile wash solution was used for leaves, flowers, and fruits. Plating was performed in triplicate using YEPD culture media (Yeast extract peptone dextrose $-1 \%$ yeast extract, $2 \%$ peptone, $2 \%$ glucose, $2 \%$ agar, $0.01 \%$ ampicillin, and $0.01 \%$ nalidixic acid dissolved in $1 \mathrm{~L}$ of distilled water), YM (Malt extract $-0.3 \%$ malt extract, $0.3 \%$ yeast extract, $0.5 \%$ peptone, $1 \%$ glucose, $2 \%$ agar dissolved in $1 \mathrm{~L}$ of distilled water) and WLN [Wallerstein nutrient broth $80 \mathrm{~g}$ of WL Nutrient medium (Acumedia ${ }^{\circledR}$ ) dissolved in $1 \mathrm{~L}$ of medium, $0.01 \%$ of ampicillin and $0.01 \%$ nalidixic acid].

\subsection{Screening of the yeast strains for antifungal activity in vitro against $P$.} italicum

To conduct the yeasts screening against $P$. italicum in addition to the 97 yeast strains obtained, six strains of Saccharomyces cerevisiae (ACBBG1, ACB-CAT1, ACB-CR1, ACB-K1, ACB-PE2, and ACB-KD1) were also tested. These strains were obtained from an ethanol fermentation, characterized by electrophoretic karyotyping and stored in the yeast collection of the Laboratory of Biochemistry and Plant Pathology at the University of São Paulo (ESALQ), Piracicaba, São Paulo, Brazil (Fialho et al., 2010).

We used the pour plate methodology, adapted from Coelho et al. (2011) with the aim to evaluate the antagonistic capacity of all 103 yeasts strains against $P$. italicum. Suspension of $100 \mathrm{~mL}$ containing $1 \times 10^{5}$ conidia/mL of pathogen was added to $900 \mathrm{~mL}$ PDA (potatodextrose-agar) around $45^{\circ} \mathrm{C}$. The culture media with the pathogen was poured into the Petri dish. After solidification the medium was perforated, leaving a $5 \mathrm{~mm}$ diameter well in the center of the plate. Then, $100 \mu \mathrm{L}$ aliquots of a suspension containing $1 \times 10^{7}$ cells $/ \mathrm{mL}$ of the yeasts strains were added into the wells. The suspensions of the yeasts were previously prepared by growing each strain, transferred from $48 \mathrm{~h}$ plate culture, into the Erlenmeyer flasks containing $25 \mathrm{~mL}$ of liquid YEPD medium. The cultures were incubated at $25^{\circ} \mathrm{C}$ on a shaker at $250 \mathrm{rpm}$ for $48 \mathrm{~h}$ and $12 \mathrm{~h}$ photoperiod.

The Petri dishes containing the pathogen and the yeasts were incubated at $22{ }^{\circ} \mathrm{C}$ photoperiod of $12 \mathrm{~h}$ for 7 days. The control corresponded to the growth of the fungus without the yeast strains. After the incubation period, the medium diameter of the halo inhibition was measured. A completely randomized design with five replications for each treatment was used. The assay was replicated. The data were subjected to analysis of variance (ANOVA). In cases of significant differences between treatments, multiple comparisons with the Tukey test $(P<0.05)$, with adjusted $P$ values.

\subsection{Antifungal activity in vivo}

'Valência' sweet orange fruits [Citrus sinensis (L.) Osbeck (Rutaceae)] in the commercial mature stage were obtained from a packinghouse in the city of Limeira, São Paulo, Brazil. We used the methodology from Ferraz et al. (2016). The untreated oranges were washed, superficially disinfected with $0.2 \%$ (v/v) sodium hypochlorite for $3 \mathrm{~min}$ and rinsed in distilled water to eliminate the sodium hypochlorite. Then, the fruits were wounded at two equidistant points, and $20 \mu \mathrm{L}$ of a $P$. italicum conidial suspension $\left(1 \times 10^{5}\right.$ conidia/mL $)$ was inoculated in the wounded area, which was treated $24 \mathrm{~h}$ later with the yeast (the curative treatment). For the preventive treatment, the fruits were wounded; the treatments were applied, and inoculated with the pathogen $24 \mathrm{~h}$ later. Eight yeast strains (ACBL-04; ACBL-05; ACBL-06; ACBL-07; ACBL-08; ACBL-10; ACBL-11 and ACBL-14) were selected based on in vitro screening to compose in vivo assay treatments. A $20 \mu \mathrm{L}$ aliquot of each treatment (yeast suspension at $1 \times 10^{7}$ cells $/ \mathrm{mL}$ ) was applied directly into the wounds in both the curative and preventive treatments. The fungicide imazalil $(2.0 \mathrm{~mL} / \mathrm{L})$ was included as chemical treatment. The positive control was fruit treated with sterile distilled water instead of another treatment. Uninoculated and untreated fruits were kept in the room to verify the possible occurrence of symptoms.

After inoculation with $P$. italicum and treatment application, the fruits were stored for 10 days in a cold chamber $\left(10 \pm 2{ }^{\circ} \mathrm{C}\right.$ and $90 \%$ $\mathrm{RH})$. Disease severity was assessed on the 8th, 9th and 10th days after inoculation by measuring the average diameter of blue mold lesions using a caliper. The incidence was expressed as the percentage of infected fruits observed at day 10 . To analyze the in vivo assays, treatments were arranged as a completely random design, with each treatment consisting of 3 replicates with 20 fruits per replicate. To analyze the effect of the treatments on the average size of the lesions caused by $P$. italicum, the area under the disease progress curve (AUDPC) was calculated and expressed by plotting the proportion of disease as a percentage versus time. According to Shaner and Finney (1977), the AUDPC can be calculated using the formula:

AUDPC $=\sum^{n-1}\left[\left(\mathrm{Y}_{\mathrm{i}+1}+\mathrm{Y}_{\mathrm{i}}\right) / 2\right] *\left[\left(\mathrm{~T}_{\mathrm{i}+1}-\mathrm{T}_{\mathrm{i}}\right)\right]$

where:

$\mathbf{n}$ - is the number of observations/evaluations;

Yi - proportion of the disease in the "i

Ti - It's the time in days in the "i"-th observation/evaluation.

The results were analyzed by variance analysis (ANOVA) and comparisons of means were performed using the Tukey test $(P<0.05)$.

\subsection{Study of action mechanisms}

In this study, eight yeast strains (ACBL-04; ACBL-05; ACBL-06; ACBL-07; ACBL-08; ACBL-10; ACBL-11 and ACBL-14) that were shown to be effective for the in vivo biocontrol of blue mold were used.

\subsubsection{Production of volatile antifungal compounds}

Each of the yeast strain was simultaneously cultivated with $P$. italicum on split plates, which prevented non-volatile compounds produced by the yeasts from reaching the fungus. A $P$. italicum culture disk ( $5 \mathrm{~mm}$ of the diameter) was placed on PDA medium on one side of the split plate. On the other side, a yeast strain culture disk $(5 \mathrm{~mm})$ was placed on YEPD medium. After incubating the fungus and different yeast strains at $22^{\circ} \mathrm{C}$ for 10 days, fungal growth was measured as the mycelial diameter in the presence of yeast relative to the mycelial diameter in the absence of the yeast (control) (Lopes et al., 2015). 


\subsubsection{Production of cell-free antifungal compounds in yeast}

For each yeast strain, a loopful of a $48 \mathrm{~h}$ culture inoculum was transferred to $250 \mathrm{~mL}$ Erlenmeyer flasks containing $50 \mathrm{~mL}$ YEPD medium, followed by incubation at $150 \mathrm{rpm}$ for $72 \mathrm{~h}$ in the dark.

Each yeast culture was filtered through Whatman $\mathrm{N}^{\circ} 4$ filter paper and a $0.45 \mu \mathrm{m}$ Millipore ${ }^{\circledR}$ membrane after incubation to remove the yeast cells according to a protocol adapted from Frighetto and Melo (1995). For each yeast cell-free filtrate, a $10 \mathrm{~mL}$ aliquot was added to $90 \mathrm{~mL}$ of melted PDA, and then poured into Petri dishes. After solidification, a $5 \mathrm{~mm} P$. italicum culture disk was placed in the center of each Petri dish. For the control, $P$. italicum was grown on PDA medium without a yeast filtrate. The cultures were incubated in a B.O.D. chamber at $22^{\circ} \mathrm{C}$ for 7 days with a $12 \mathrm{~h}$ photoperiod, and $P$. italicum growth was assessed by measuring the mean diameter of each colony in two perpendicular directions.

\subsubsection{Production of thermostable antifungal compounds}

For each yeast strain tested, a yeast culture disk was transferred to $250 \mathrm{~mL}$ Erlenmeyer flasks containing $50 \mathrm{~mL}$ YEPD medium and, incubated at $150 \mathrm{rpm}$ for $72 \mathrm{~h}$ in the dark. A $10 \mathrm{~mL}$ aliquot of each strain was transferred to Erlenmeyer flasks containing $90 \mathrm{~mL}$ PDA medium and sterilized (at $121^{\circ} \mathrm{C}$ for $20 \mathrm{~min}$ ). Each sterilized medium was poured into a Petri dish, and after it solidified, a $5 \mathrm{~mm} P$. italicum culture disk was placed in the center of each plate. For the control, $P$. italicum was grown on PDA medium without metabolites. The cultures were kept in B.O.D. chamber at $22^{\circ} \mathrm{C}$ for 7 days, and the growth of $P$. italicum growth was assessed by measuring the mean diameter of each colony in two perpendicular directions. This methodology was according to Ferraz et al. (2016).

\subsubsection{Detection of 'killer' activity by yeast isolates}

This assay was conducted according the methodology described by Ceccato-Antonini et al. (2004) methodology. A $1.0 \times 10^{5}$ cell/mL suspension of S. cerevisiae NCYC 1006 ('killer' factor sensitive) was prepared by culturing in YEPD medium at $28^{\circ} \mathrm{C}$ for $24 \mathrm{~h}$. A $100 \mu \mathrm{L}$ aliquot of the suspension was transferred to a Petri dish containing YEPD-methylene blue medium buffered at $\mathrm{pH}$ 4.3-4.7. To evaluate the presence of 'killer' factor, each yeast strain was spotted on separate Petri dishes with sterile toothpicks, and the cultures were incubated at $28^{\circ} \mathrm{C}$ for 3 days. The production of 'killer' factor and the death of sensitive cells were indicated by the presence of a growth inhibition zone and an adjacent blue zone.

\subsubsection{Nutrient competition}

This assay was conducted according to Ferraz et al. (2016) methodology. To evaluate nutrient competition between $P$. italicum and antagonistic yeasts, agar-coated microscope slides were prepared with varying glucose concentrations $(0 \%, 0.5 \%, 1 \%, 1.5 \%, 2 \%$, and $2.5 \%)$. For each yeast strain tested, $10 \mu \mathrm{L}$ of a $P$. italicum suspension $\left(1 \times 10^{5}\right.$ conidia/mL) and $10 \mu \mathrm{L}$ of a yeast suspension $\left(1 \times 10^{8}\right.$ cells/ $\mathrm{mL}$ ) were spotted onto pre-marked locations on the slides, and the cultures were incubated in a B.O.D. chamber at $22^{\circ} \mathrm{C}$ for $17 \mathrm{~h}$. The nutrient competition was assessed by counting the number of germinated and no-germinated conidia among 100 randomly selected conidia. Conidia were considered fully germinated when the length of the germ tube was at least the size of the swollen conidia. The factorial design with eight replicates per treatment was used for this assay.

\subsubsection{Evaluation of the mycelial growth of Penicillium italicum collected} from the antagonism zone

$P$. italicum was co-cultured on Petri dishes with each yeast strain studied, according to the methodology described by Dennis and Webster (1971). The test was performed on Petri dishes containing PDA medium by placing a $0.5 \mathrm{~cm} \mathrm{P}$. italicum mycelial disk on one side of the plate and a $0.5 \mathrm{~cm}$ yeast strain culture disk $3 \mathrm{~cm}$ away. For a more detailed characterization of the inhibition zone formed after co-culture of the antagonistic yeast strains and fungus, hyphal viability and mycelial growth of the pathogen was quantified in the antagonism zone (i.e., the area adjacent to the fungal inhibition zone). To measure mycelial growth, $0.5 \mathrm{~cm}$ mycelial disks were cut from the following three sections of each plate and compared: the inhibition zone, the zone adjacent to the inhibition zone (intermediate zone), and the zone furthest from the inhibition zone where mycelia were not inhibited by yeast (distant zone). The cultures were incubated in a B.O.D. chamber at $22{ }^{\circ} \mathrm{C}$ for 10 days with a $12 \mathrm{~h}$ photoperiod, after which the mycelial growth diameter of $P$. italicum was measured in two perpendicular directions.

\subsubsection{Production of hydrolytic enzymes}

The production and secretion of hydrolytic enzymes by the yeast strains were analyzed according to the methodology of Fialho (2005). A loopful for each strain was transferred to $20 \mathrm{~mL}$ liquid YEPD medium and incubated at $150 \mathrm{rpm}$ for $72 \mathrm{~h}$ in the dark. Thereafter, $1 \mathrm{~mL}$ of each suspension was transferred to $15 \mathrm{~mL}$ Falcon tubes containing $10 \mathrm{~mL}$ YEPD or modified YEPD medium (containing $P$. italicum cell wall preparation in place of $1 \%$ glucose). The cultures were prepared in triplicate and incubated at $150 \mathrm{rpm}$. After a $24 \mathrm{~h}$ incubation period, a $1.5 \mathrm{~mL}$ volume was aliquoted and centrifuged at $3000 \mathrm{rpm}$ for $10 \mathrm{~min}$. The supernatant was recovered and used for the quantification of $\beta-1,3$ glucanase and chitinase.

A protocol adapted from Bar-Shimon et al. (2004) was used for the cell wall preparation. Briefly, $1 \mathrm{~mL}$ of a $P$. italicum suspension $\left(1.0 \times 10^{5}\right.$ conidia $\left./ \mathrm{mL}\right)$ was cultured in $50 \mathrm{~mL}$ PD medium at $150 \mathrm{rpm}$ for 8 days. Mycelial contents were recovered by filtration through Whatman $\mathrm{N}^{\mathrm{o}}$. 1 filter paper then washed three times with distilled water, homogenized in $0.1 \mathrm{M}$ phosphate buffer ( $\mathrm{pH} 7.2$ ) for $2 \mathrm{~min}$, and stored at $-20^{\circ} \mathrm{C}$ overnight. After thawing and homogenization, approximately $20 \mathrm{~mL}$ of the fungal mycelia were transferred to a vial and macerated in liquid nitrogen, and the fungal cell wall preparation was stored at $-80{ }^{\circ} \mathrm{C}$ until use.

2.5.7.1. Quantification of reducing sugars. The reducing sugars released during the enzymatic activity assays were quantified using the 3,5dinitrosalicylic acid (DNS) method described by Miller (1959).

2.5.7.2. Quantification of $\beta-1,3$-glucanase enzymatic activity. To assess the production of $\beta-1,3$-glucanases, a colorimetric assay was used to quantify glucose released from the laminarin substrate along with the method for the quantification of reducing sugars (Section 2.5.7.1). The reaction was performed using $200 \mu \mathrm{L}$ McIlvaine buffer (pH 6.0), $100 \mu \mathrm{L}$ culture sample, and $100 \mu \mathrm{L}$ laminarin $(4 \mathrm{mg} / \mathrm{mL})$. The reaction was incubated at $50{ }^{\circ} \mathrm{C}$ for $1 \mathrm{~h}$ then stopped using $200 \mu \mathrm{L}$ DNS for the reducing sugar quantification. Absorbance readings at $540 \mathrm{~nm}$ were subtracted from the absorbance of the reaction mixture in the presence of a buffer solution (in place of the culture medium). Additionally, the absorbance of a negative control (a buffer solution in place of the substrate) was subtracted from each experimental reading. Absorbance values were plotted on a standard curve of glucose, and enzymatic activity was expressed in U/L, where a unit of activity (U) was defined as $1.0 \mathrm{~g}$ of reducing sugar (glucose) released from laminarin under the assay conditions used.

2.5.7.3. Quantification of chitinase enzymatic activity. The chitinase production was quantified as the amount of $N$-acetyl glucosamine (NAG) released from glycol chitin substrate. Briefly, $100 \mu \mathrm{L}$ of each yeast culture was mixed with $200 \mu \mathrm{L}$ McIlvaine buffer (pH 6.0) and $100 \mu \mathrm{L} 0.01 \%$ glycol chitin (w/v) in the same buffer. After incubation at $50{ }^{\circ} \mathrm{C}$ for $60 \mathrm{~min}$, the reaction was stopped with $200 \mu \mathrm{L}$ DNS, and reducing sugar quantification was performed as previously described. A solution containing reaction mixture combined with buffer solution (in place of culture medium) was used as the reagent blank. Absorbance readings were also subtracted from a negative control reading (buffer 

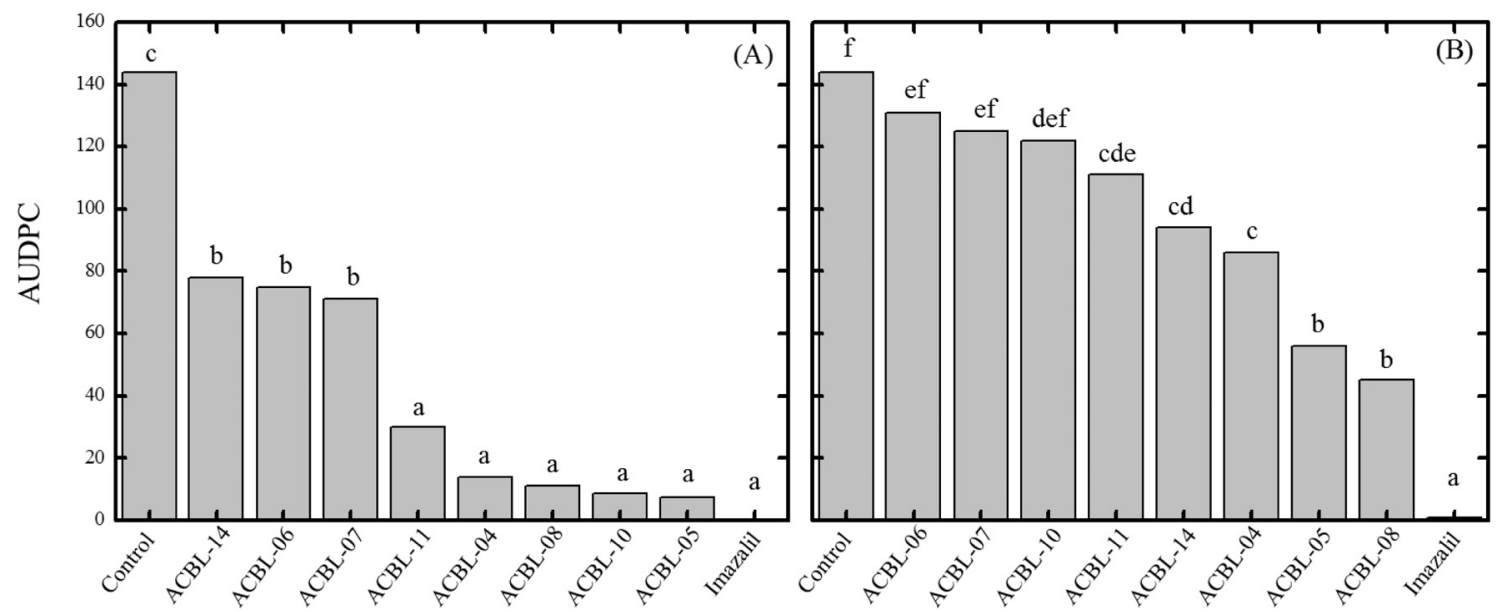

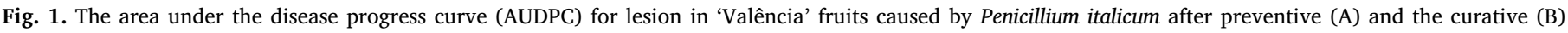
treatment, kept in cold chamber $\left(10 \pm 2{ }^{\circ} \mathrm{C}\right)$ for 10 days. Statistical significance determined at $P<0.05$ according to Tukey test.

solution in place of the glycol chitin substrate). Enzymatic activity was expressed in $\mathrm{U} / \mathrm{L}$, where $\mathrm{U}$ was defined as $1.0 \mathrm{~g}$ of reducing sugar $(\mathrm{N}$ acetylglucosamine) enzymatically released from glycol chitin under the assay conditions used.

\subsubsection{Statistical analysis}

A completely randomized design with five replicates was used to quantify the production of antifungal compounds and to evaluate the mycelial growth of $P$. italicum collected from the antagonism zone. The data were analyzed by ANOVA, and the mean values were compared with Tukey's test at the 5\% significance level. A factorial design with eight replicates per treatment was used to assess the nutrient competition. The mean values for each treatment were compared using Tukey's test at the 5\% significance level. All assays were performed in duplicate, and the ASSISTAT software was used for the statistical analysis.

\subsection{Molecular identification of the most effective yeast strain}

Eight yeast strains (ACBL-04, ACBL-05, ACBL-06, ACBL-07, ACBL08, ACBL-10, ACBL-11 and ACBL-14) were identified by genetic material using molecular biology techniques. Yeast isolates were growth in YEPD medium at $28^{\circ} \mathrm{C}$ for $24 \mathrm{~h}$ and the DNA extraction were performed using the Wizard Genomic DNA Purification Kit - Promega ${ }^{\circledR}$ according recommendation DNA quantity and purity was measured at A260, A280 and A260/A280 using a NanoDrop 2000c.

The amplification of the ITS region (Internal Transcribed Spacer) of the rRNA gene including the 5.8S gene was performed by PCR using the primers: forward-ITS1 (TCCGTAGGTGAACCTGCGG) and reverse-ITS4 ( TCCTCCGCTTATTGATATGC), according to the White et al. (1994).

PCR products were purified from agarose gel using a "PureLink ${ }^{\mathrm{rm}}$ Quick Gel Extraction and PCR Purification Combo Kit" (Invitrogen ${ }^{\mathrm{TM}}$ ) which is commercially available. For the sequencing of the ITS region of the rRNA gene, the reaction consisted of $3 \mu \mathrm{L}$ of purified PCR product, $0.5 \mu \mathrm{L}(100 \mu \mathrm{M})$ of the primer (ITS- 1 or ITS-4), $0.4 \mu \mathrm{L}$ of Big Dye Terminator Kit (Applied Biosystems), $2 \mu \mathrm{L}$ of SM buffer and sterile Milli$\mathrm{Q}$ water to complete $10 \mu \mathrm{L}$. Sequencing reactions for the rRNA gene were carried out using the ABI3730 automated sequencer (Applied Biosystems). The sequences obtained were aligned and compared with the at the National Centre of Biotechnology Information (NCBI) database by the website using Basic Local Alignment Search Tool (BLAST) (Thompson et al., 1994) and after identification, the sequences were deposited in the GenBank.

\section{Results}

\subsection{Yeasts isolation}

Ninety-seven isolates were obtained, of which $55.8 \%$ were from citrus leaves, $21 \%$ from fruits, $13.7 \%$ from flowers and $9.5 \%$ from soil. The highest percentage of isolates was obtained on YEPD medium (49.5\% of the total), followed by WLN (28.4\%) and YM $(22.1 \%)$. The isolation-source of the yeasts selected to in vivo assays - ACBL-04, ACBL05, ACBL-06, ACBL-07, ACBL-08, and ACBL-10 - were obtained from the citrus leaves, and strains ACBL- 11 and ACBL-14 were isolated from citrus flowers in the same citrus-crop, localized in Leme, SP, Brazil.

\subsection{Screening of the yeast strains for antifungal activity in vitro against $P$. italicum}

Of the 103 yeast strains tested in vitro (97 yeast isolates plus six strains of $S$. cerevisiae) for $P$. italicum antagonism, 61 were able to inhibit mycelial growth of the fungus (ranging from 10 to $100 \%$ of inhibition). Among the strains with the pour plate technique, seven strains inhibited $>80 \%$ of mycelial growth-in decreasing order of inhibition power: ACBL-08, ACBL-07, ACBL-11, ACBL-05, ACBL-06, ACBL-14 and ACBL-10. The ACBL-04 strain promoted 100\% inhibition. These eight strains were therefore selected for the in vivo assays (Supplementary data).

\subsection{Antifungal activity in vivo}

When 'Valência' sweet orange fruits were treated preventively, all eight strains reduced the development of the average size of the fruits lesions. The best preventive treatments achieved with the yeasts strains were: ACBL-05, ACBL-10, ACBL-08, ACBL-04, and ACBL-11 in this order (Figs. 1-A and 2). For curative treatment trials, the best results were displayed with the five following yeasts strains: ACBL-08, ACBL05, ACBL-04, ACBL-14, and ACBL-11 in this order (Fig. 1-B). The fungicide imazalil control samples promoted the best curative results and did not significantly differed from the strains ACBL-05, ACBL-10, ACBL08, ACBL-04 and ACBL-11 in the preventive treatment. The fruits untreated and uninoculated did not show blue mold symptoms. Apparently, the yeasts influenced the blue mold and did not cause damages to the fruits.

For preventive treatments, the best results regarding the percentage of healthy fruits were achieved according to the following order: ACBL05 (92\%), ACBL-10 (83\%), ACBL-08 (78\%) and ACBL-04 (75\%) (Figs. 3-A and 2). For curative treatment, the strain ACBL-08 was able 


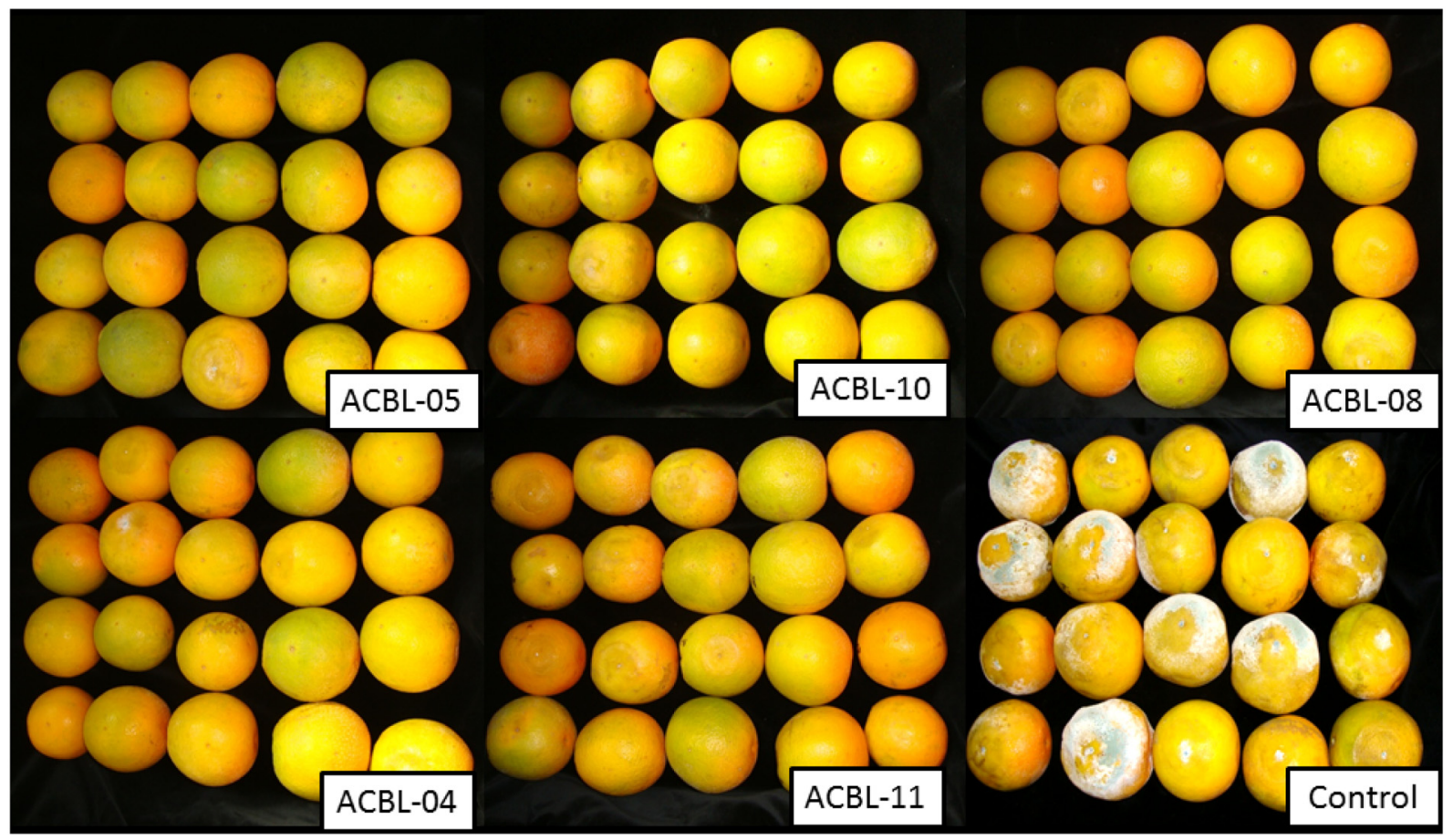

Fig. 2. Fruits of 'Valência' after preventive treatments application, they were kept for 10 days in a cold chamber $\left(10 \pm 2{ }^{\circ} \mathrm{C}\right.$ and $\left.90 \% \mathrm{RH}\right)$. Yeast strains (treatments): ACBL-05, ACBL-10, ACBL-08, ACBL-04, and ACBL-11. Control: fruits treated with sterile distilled water with blue mold symptoms. (For interpretation of the references to color in this figure legend, the reader is referred to the web version of this article.)

to reduce the occurrence of symptomatic fruits with blue mold by $57 \%$ of lesion fruits (Fig. 3-B). The fungicide imazalil control samples promoted the best curative results and did not significantly differed from the strains ACBL-05, ACBL-10, ACBL-08 and ACBL-04 in the preventive treatment.

\subsection{Study of action mechanisms}

\subsubsection{Production of antifungal compounds}

All the yeast strains evaluated did not produce cell-free and thermostable antifungal compounds in sufficient amounts to inhibit the mycelial growth of $P$. italicum.

\subsubsection{Detection of 'killer' activity by yeast isolates}

Three yeast strains (ACBL-05, ACBL-07 and ACBL-08) exhibited 'killer' activity, they produced a blue inhibition ring or zone (indicative of cell death) and five strains produced a clear zone (indicative of inhibitory activity without cell death) around each colony, as illustrated in Fig. 4.

\subsubsection{Nutrient competition}

All of the yeast strains tested inhibited the germination of $P$. italicum conidia, regardless of the glucose concentration used (Fig. 5). ACBL-07 and ACBL-08 strains exhibited the greatest inhibition of conidial germination, with $78.18 \%$ and $68.20 \%$ inhibition, respectively.

\subsubsection{Evaluation of the mycelial growth of Penicillium italicum collected} from the antagonism zone

The mycelial growth analysis indicated that none of the yeast strains affected the viability of hyphae ( $P$. italicum) removed from the antagonism zone. Additionally, the growth of pathogen collected from the intermediate and distal zones was unaffected.

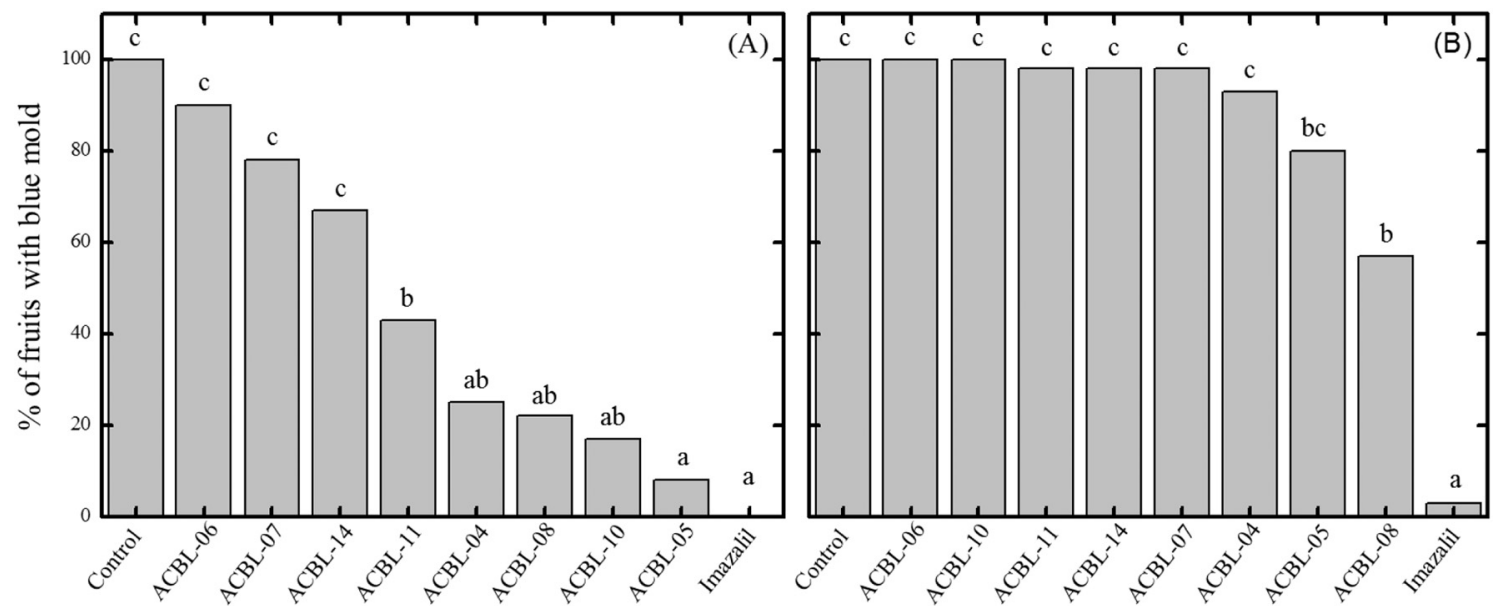

Fig. 3. Incidence (\%) of 'Valência' fruits with blue mold symptoms after preventive (A) and curative (B) treatment with yeast isolates, kept in a cold chamber $\left(10 \pm 2{ }^{\circ} \mathrm{C}\right)$ for 10 days. Statistical significance determined at $P<0.05$ according to Tukey test. 


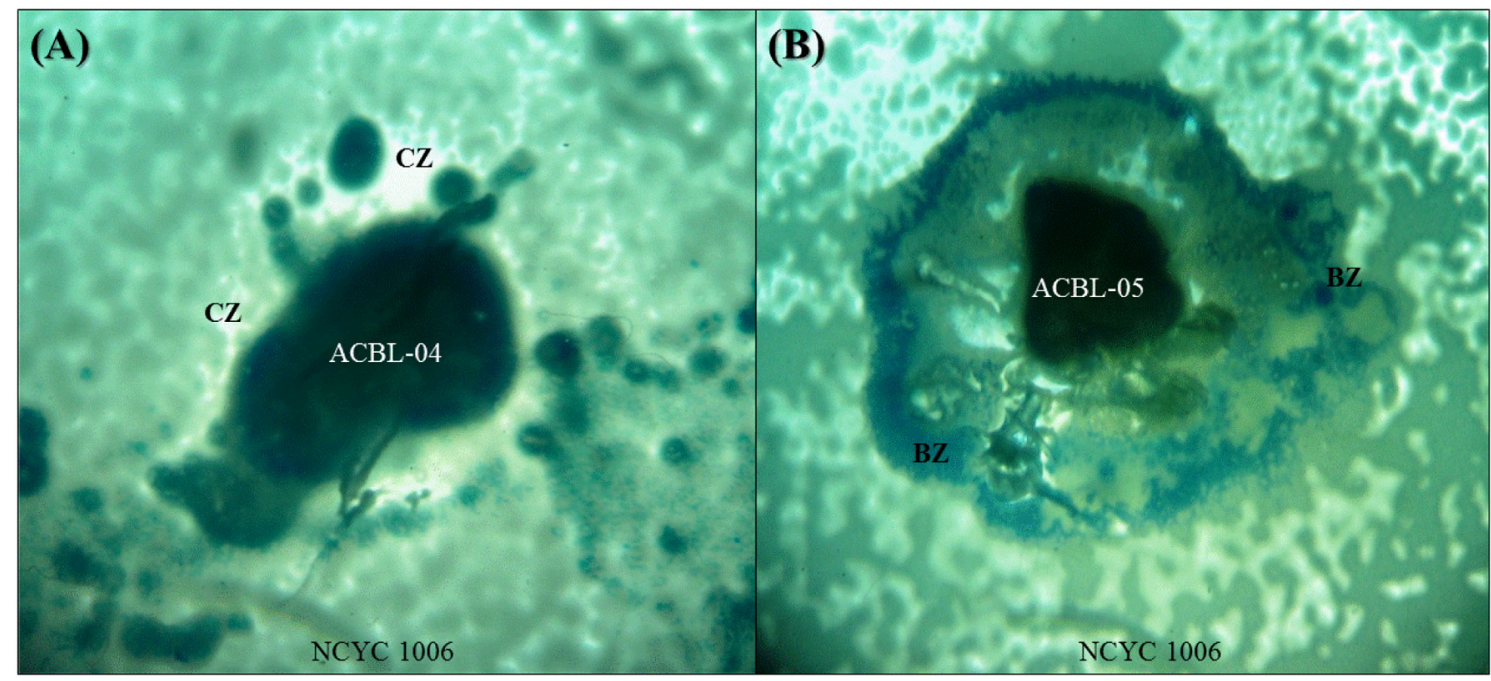

Fig. 4. (A) ACBL-04 'killer' activity showed clear zone (CZ) (indicative of inhibition of the susceptible yeast isolate Saccharomyces cerevisiae NCYC 1006). (B) ACBL-05 'killer' activity with a blue zone (BZ) (indicative of S. cerevisiae NCYC 1006 cell death) on YEPD-methylene blue medium (pH 4.5) at $28{ }^{\circ} \mathrm{C}$. (For interpretation of the references to color in this figure legend, the reader is referred to the web version of this article.)

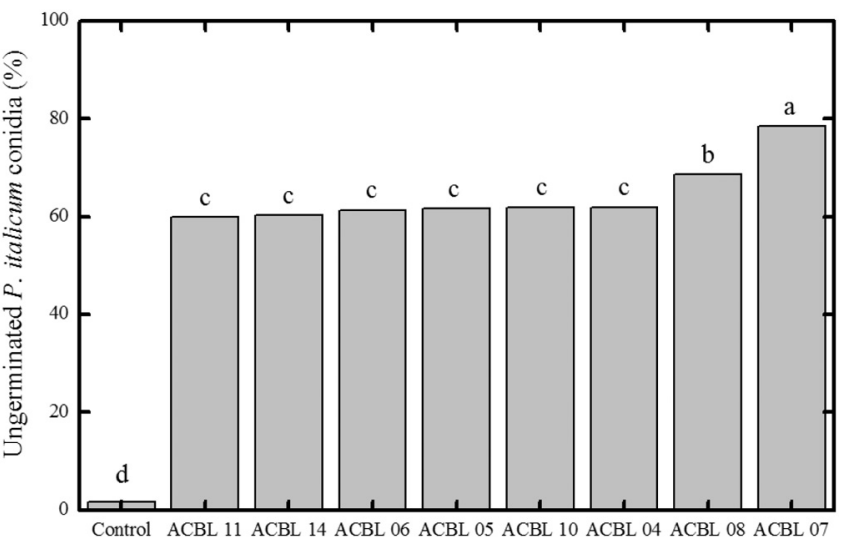

Fig. 5. Effect of yeast isolates on the conidial germination of Penicillium italicum grown on agar medium with different glucose concentrations at $22{ }^{\circ} \mathrm{C}$. Mean values (represented by bar height) marked with the same letter are not significantly different according to Tukey's test $(P<0.05)$.

\subsubsection{Production of hydrolytic enzymes}

The findings indicated that ACBL-04, ACBL-7 and ACBL-11 were the only strains that exhibited chitinase activity $(0.007,0.003$, and $0.031 \mathrm{~g} /$ $\mathrm{L}$, respectively). The others strain no exhibited chitinase and $\beta-1,3-$ glucanase activity.

\subsection{Molecular identification of the most effective yeast strain}

The most effective yeast isolates for the control of citrus blue mold were identified as: Candida stellimalicola to strains ACBL-04 (GenBank accession number: MH001971), ACBL-05 (MH001972), ACBL-06 (MH001973), ACBL-07 (MH001974), ACBL-08 (MH001975), and Saccharomyces cerevisiae to strains ACBL-11 (MH001976) and ACBL-14 (MH001970). The strain ACBL-10 was not identified by molecular technics.

Candida sp. strains were similar with 5.8S ribosomal RNA gene, ACBL-04 (95\% of ident), ACBL-05 (97\%), ACBL-06 (97\%), ACBL-07 (96\%), ACBL-08 with $99 \%$ of identity. The strains ACBL-11 and ACBL14 were identified as $S$. cerevisiae with by partial sequence $5.8 \mathrm{~S}$ rRNA gene, both with $99 \%$ of similarity.

\section{Discussion}

In our study, we isolated and selected yeasts from citrus leaves, flowers, fruits, and citrus soils. Also, we determined the most effective yeast strains for the biocontrol of blue mold of 'Valência' sweet oranges. Surfaces of leaves and fruits are suitable for the isolation of antagonistic microorganisms such as yeast strains, due to their quick colonization facilitated by the high sugar content of these environments (Sharma et al., 2009). Our results indicated that the phylloplane was the main source to obtain yeast strains $(90.5 \%)$, they were similar by other authors (Cabral et al., 2009; Chanchaichaovivat et al., 2007; Ferraz et al., 2016; Rosa-Magri et al., 2011; Wang et al., 2009).

Evaluating the incidence and severity of blue mold on 'Valência' sweet oranges (Figs. 1 and 3), we demonstrated that the yeast strains ACBL-04, ACBL-05, ACBL-08, ACBL-10 and ACBL-11 were most effective when applied preventively rather than curatively. Other reports are in agreement with these results (Demirci, 2011; Guo et al., 2014; Lu et al., 2013).

Lu et al. (2013) study the effect of preventive treatment of coldstored $\left(10^{\circ} \mathrm{C}\right.$ to $\left.15^{\circ} \mathrm{C}\right)$ lemon fruits with Debaryomyces hansenii showed that yeasts at $1 \times 10^{8}$ cells $/ \mathrm{mL}$ were able to confer protection to $P$. italicum (Blue mold). The protection in a room $\left( \pm 22^{\circ} \mathrm{C}\right)$ and cold temperatures $\left(10^{\circ} \mathrm{C}\right)$ was similar to that obtained with imazalil when the yeasts were used preventively. Their results agree with our assays.

Most postharvest infections occur through wounds caused in the fruits during harvest or soon after in the packinghouses. Thus, the preventive control of blue mold through an application of yeasts during pre-harvest may allow better protection of fruits to the pathogens that occur in the post-harvest (Usall et al., 2008). Our in vivo results revealed that the C. stellimalicola (ACBL-05) produced the best control (above $90 \%$ ) of blue mold on 'Valência' sweet orange fruits when it was applied preventively. This data demonstrates the potential use of this strain for the biocontrol of citrus blue mold disease in the packinghouse. Studies by Long et al. (2005) demonstrated high levels (up to 100\%) of control of $P$. italicum induced blue mold disease in citrus using the yeast Klockera apiculata.

In our study, the in vivo assays were performed in cold chamber, suggesting that the antagonist yeasts studied endure storage at low temperatures. This characteristic turns them potential agents for the biocontrol of blue mold in citrus fruit because these fruits are commonly stored under refrigerated conditions to control diseases of fruits and vegetables after harvest (Zhang et al., 2005). However, before 
reaching commercial use, further studies should be conducted to assess whether these yeast strains can keep their biocontrol abilities at different temperatures ranges to endure the needs of a supply chain of citrus fruit. Human health safety studies will also definitely be needed.

We explore the mechanisms which these antagonistic yeasts interact with $P$. italicum to promote the biocontrol of citrus blue mold disease. It was verified that three yeasts strains analyzed were able to produce 'killer' toxin, supporting that this compound is one of the main modes of action for the biocontrol of $P$. italicum. These results corroborate with data reported by other authors that found the susceptibility of pathogens to the mycocinogenic yeasts, enhancing the prospects of application of this group of antagonists (Coelho, 2005; Lima et al., 2013; Platania et al., 2012; Santos et al., 2004; Walker et al., 1995; Weiler and Schmitt, 2003).

The 'killer' activity in diverse genera and species of yeasts has been extensively studied and it has reached important industrial recognitions (Aladdin et al., 2018). Especially, the use of killer yeasts as biological control agents of fungi responsible for post-harvest diseases of fruits and vegetables are being investigated more in the last two decades (Parafati et al., 2016; Perez et al., 2018). For example, Grzegorczyk et al. (2017), reported the antagonist effects from 'killer' yeasts Debaryomyces hansenii KI2a, D. hansenii MI1a and Wickerhamomyces anomalus BS91 against Monilinia fructigena and M. fructicola, when tested in vitro and in vivo conditions. Parafati et al. (2015), also observed high 'killer' activity from $W$. anomalus and $S$. cerevisiae in the biocontrol of Botrytis cinerea.

The in vitro assay showed that $58 \%$ of the yeast strains inhibited the mycelial growth of the phytopathogen, and among the best were the strains ACBL-04, ACBL-05, ACBL-06, ACBL-07, ACBL-08, and ACBL-11 reaching inhibition values above $90 \%$. Possibly these yeasts strains were the best in the biocontrol of $P$. italicum due to biocontrol mechanisms by which these yeasts interact with the pathogen such as chitinase production, toxin 'killer' and inhibited the germination of conidia. S. cerevisiae strain ACBL-14 inhibited $86 \%$ of $P$. italicum mycelial growth in vitro. This data agree with the study by Zhang et al. (2005), which demonstrated that Cryptococcus laurentii was able to inhibit the conidial germination of $P$. italicum in postharvest oranges. Other studies have been implicated yeasts in the biocontrol of $P$. italicum in vitro (P. Liu et al., 2013; McKay et al., 2012).

To our knowledge, this is the first report of C. stellimalicola as biological control agents against a postharvest pathogen to citrus fruit when used preventively. Our results indicated the multiple modes of action against the pathogen presented by $C$. stellimalicola strains (ACBL04, ACBL-05, and ACBL-08), as 'killer' activity, production of chitinase and inhibition of conidial germination, may explain why these yeasts provided control of $P$. italicum under in vitro and in vivo conditions. Therefore, in conclusion, these strains of yeast are not pathogenic to plants and so have utility against $P$. italicum as an alternative postharvest control in citrus fruits. However, the postharvest formulations must be further studied before it is practical and effective to use them as biological control agents, and later studies will be required to elucidation the 'killer' toxin produced by these strains.

Supplementary data to this article can be found online at https:// doi.org/10.1016/j.ijfoodmicro.2018.03.019.

\section{Acknowledgements}

The financial support of the FAPESP (The State of São Paulo Research Foundation) (grant number 2011/13006-1), which provided a scholarship to Tatiane da Cunha (grant number 2011/13874-3), is gratefully acknowledged.

\section{References}

Aladdin, A., Malek, R.A., El Enshasy, H.A., et al., 2018. In: Zakaria, Z.A. (Ed.), Killer Yeast, a Novel Biological Control of Soilborne Diseases for Good Agriculture Practice.
Sustainable Technologies for the Management of Agricultural Wastes, Applied Environmental Science and Engineering for a Sustainable Future Springer Nature Singapore Pte Ltd., pp. 71-86. http://dx.doi.org/10.1007/978-981-10-5062-6_6.

Azeredo, L.A.I., Gomes, E.A.T., Mendonça-Hagler, L.C., Hagler, A.N., 1998. Yeast communities associated with sugarcane in Campos, Rio de Janeiro, Brazil. Int. Microbiol. 1, 205-208.

Bar-Shimon, M., Yehuda, H., Cohen, L., Wiess, B., Kobeshnikov, A., Daus, A., Goldway, M., Wisniewski, M.E., Droby, S., 2004. Characterization of extracellular lytic enzymes produced by the yeast bicontrol agent Candida oleophila. Cur. Genet. 45, 140-148.

Cabral, A.S., Carvalho, P.M.B., Pinotti, T., Hagler, A.N., Mendonça-Hagler, L.C.S., Macrae, A., 2009. Yeast inhibits the growth of the phytopathogen Moniliophthora perniciosa, the causal agent of 'witches' broom disease. Braz. J. Microbiol. 40, 108-110.

Ceccato-Antonini, S.R., Tosta, C.D., Silva, A.C., 2004. Determination of yeast killer activity in fermentation sugarcane juice using selected ethanol-making strains. Braz. Arch. Biol. Technol. 47, 13-23.

Chanchaichaovivat, A., Ruenwongsa, P., Panijpan, B., 2007. Screening and identification of yeast strains from fruits and vegetables: potential for biological control of postharvest chilli anthracnose (Colletotrichum capsici). Biol. Control 42, 326-335.

Coelho, A.R., 2005. Controle de Penicillium expansum/Biodegradação de Patulina: Perfil cromatográfico de composto bioativo de leveduras killer visando aplicação pós-colheita. Universidade Estadual de Londrina, Londrina, pp. 130.

Coelho, A.R., Nóbrega, G.M.A., Pagnocca, F.C., Hoffmann, F.L., Harada, K., Hirooka, E.Y., 2011. Avaliação do potencial antagônico de leveduras, visando biocontrole de deterioração por Penicillium expansum. Semina: Ciências Agrárias 32, 1879-1892.

Demirci, F., 2011. Effects of Pseudomonas fluorescens and Candida famata on blue mould of citrus caused by Penicillium italicum. AJCS 5, 344-349.

Dennis, C., Webster, J., 1971. Antagonistic properties of species groups of Trichoderma III. Hyphal interactions. Trans. Brit. Mycol. Soc. 57, 359-363.

Ferraz, L.P., da Cunha, T., da Silva, A.C., Kupper, K.C., 2016. Biocontrol ability and putative mode of action of yeasts against Geotrichum citri-aurantii in citrus fruit. Microbiol. Res. 188, 72-79.

Fialho, M.B., 2005. Efeito in vitro de Saccharomyces cerevisiae sobre Guignardia citricarpa, agente causal da pinta preta dos citros. 60p. Escola Superior de Agricultura "Luiz de Queiroz". Universidade de São Paulo, Piracicaba/SP.

Fialho, M.B., Toffano, L., Pedroso, M.P., Augusto, F., Pascholati, S.F., 2010. Volatile organic compounds produced by Saccharomyces cerevisiae inhibit the in vitro development of Guignardia citricarpa, the causal agent of citrus black spot. W. J. Microbiol. Biotech. 26, 925-932.

Frighetto, R.T.S., Melo, I.S., 1995. Produção de antibióticos por microrganismos. Coords. In: de Melo, I.S., Sanhueza, R.M.V. (Eds.), Métodos de seleção de microrganismos antagônicos a fitopatógenos. Jaguariúna: EMBRAPA-CNPMA, pp. 40-46.

Fu, L.H., Hu, K.D., Hu, L.Y., Li, Y.H., Hu, L.B., et al., 2014. An antifungal role of hydrogen sulfide on the postharvest pathogens Aspergillus niger and Penicillium italicum. PLoS One 9 (8), e104206.

García-Cela, E., Crespo-Sempere, A., Ramos, A.J., Sanchis, V., Marin, S., 2014. Ecophysiological characterization of Aspergillus carbonarius, Aspergillus tubingensis and Aspergillus niger isolated from grapes in Spanish vineyards. Int. J. Food Microbiol. 173, 89-98.

Grzegorczyk, M., Zarowska, B., Restuccia, C., Cirvilleri, G., 2017. Postharvest biocontrol ability of killer yeasts against Monilinia fructigena and Monilinia fructicola on stone fruit. Food Microbiol. 61, 93-101.

Guo, J., Fangc, W., Lua, H., Zhua, R., Lua, L., Zhenga, X., Yua, T., 2014. Inhibition of green mold disease in mandarins by preventive applications of methyl jasmonate and antagonistic yeast Cryptococcus laurentii. Post. Biol. Technol. 88, 72-78.

Hernández-Montiel, L.G., Ochoa, J.L., Troyo-Diéguez, E., Larralde-Corona, C.P., 2010. Biocontrol of postharvest blue mold (Penicillium italicum Wehmer) on Mexican lime by marine and citrus Debaryomyces hansenii isolates. Post. Biol. Technol. 56, 181-187.

Hodges, R.J., Buzby, J.C., Bennett, B., 2011. Postharvest losses and waste in developed and less developed countries: opportunities to improve resource use. J. Agric. Sci. 149, 37-45.

Lahlali, R., Serrhini, M.N., Frie, D., Jijakli, M.H., 2006. In vitro effects of water activity, temperature and solutes on the growth rate of $P$. italicum Wehmer and $P$. digitatum Sacc. J. Appl. Microbiol. 101, 628-636.

Lahlali, R., Hamadi, Y., Drider, R., Misson, C., El Guilli, M., Jijakli, M.H., 2014. Control of citrus blue mold by the antagonist yeast Pichia guilliermondii Z1: compatibility with commercial fruit waxes and putative mechanisms of action. Food Control 45, 8-15.

Lima, J.R., Gonçalves, L.R.B., Brandão, L.R., Rosa, C.A., Viana, F.M.P., 2013. Isolation, identification, and activity in vitro of killer yeasts against Colletotrichum gloeosporioides isolated from tropical fruits. J. Basic Microbiol. 53, 590-599.

Liu, J., Sui, Y., Wisniewski, M., Droby, S., Liu, Y., 2013. Review: utilization of antagonistic yeasts to manage postharvest fungal diseases of fruit. Int. J. Food Microbiol. 167, $153-160$.

Liu, P., Luo, L., Long, C., 2013. Characterization of competition for nutrients in the biocontrol of Penicillium italicum by Kloeckera apiculata. Biol. Control 67, 157-162.

Liu, P., Cheng, Y., Yang, M., Liu, Y., Chen, K., Long, C., Deng, W., 2014. Mechanisms of action for 2-phenylethanol isolated from Kloeckera apiculata in control of Penicillium molds of citrus fruits. BMC Microbiol. 14, 242.

Long, C.A., Wu, Z., Deng, B.W., 2005. Biological control of Penicillium italicum of citrus and Botrytis cinerea of grape by strain 34-9 of Kloeckera apiculata. Eur. Food Res. Technol. 221, 197-201.

Lopes, M.R., Klein, M.N., Ferraz, L.P., Silva, A.C., Kupper, K.C., 2015. Saccharomyces cerevisiae: a novel and efficient biological control agent for Colletotrichum acutatum during pre-harvest. Microbiol.Res. 175, 93-99.

Lu, L., Ye, C., Guo, S., Sheng, K., Shao, L., Zhou, T., Yu, T., 2013. Preharvest application of antagonistic yeast Rhodosporidium paludigenum induced resistance against postharvest diseases in mandarin orange. Biol. Control 67, 130-136. 
McKay, A.H., Föster, H., Adaskaveg, J.E., 2012. Distinguishing Galactomyces citri-aurantii from G. geotrichum and characterizing population structure of the two postharvest sour rot pathogens of fruit crops in California. Phytopathology 102, 528-538.

Miller, G.H., 1959. Use of dinitrosalicylic acid reagent for determination of reducing sugar. Anal. Chem. 31, 426-429.

Moretto, C., Cervantes, A.L.L., Batista Filho, A., Kupper, K.C., 2014. Integrated control of green mold to reduce chemical treatment in post-harvest citrus fruits. Sci. Horticul. 165, 433-438.

Palou, L., Usall, J., Muñoz, J.A., Smilanick, J.L., Viñas, I., 2002. Hot water, sodium carbonate, and sodium bicarbonate for the control of postharvest green and blue molds of clementine mandarins. Post. Biol. Technol. 24, 93-96.

Parafati, L., Vitale, A., Cirvilleri, G., 2015. Biocontrol ability and action mechanism of food-isolated yeast strains against Botrytis cinerea causing post-harvest bunch rot of table grape. Food Microbiol. 47, 85-92.

Parafati, L., Cirvilleri, G., Restuccia, C., Wisniewski, M., 2016. Potential role of exoglucanase genes (waexg1 and waexg2) in the biocontrol activity of Wickerhamomyces anomalus. Microb. Ecol. http://dx.doi.org/10.1007/s00248-016-0887-5.

Perez, M.F., Isas, A.S., Aladdin, A., El Enshasy, H.A., Dib, J.R., 2018. In: Zakaria, Z.A. (Ed.), Killer Yeasts as Biocontrol Agents of Postharvest Fungal Diseases in Lemons. Sustainable Technologies for the Management of Agricultural Wastes, Applied Environmental Science and Engineering for a Sustainable Future 71. Springer Nature Singapore Pte Ltd., pp. 87-98. http://dx.doi.org/10.1007/978-981-10-5062-6_6.

Platania, C., Restuccia, C., Muccili, S., Cirvilleri, G., 2012. Efficacy of killer yeasts in the biological control of Penicillium digitatum on Tarocco orange fruits (Citrus sinensis). Food Microbiol. 30, 219-225.

Rosa-Magri, M.M., Tauk-Tornisielo, S.M., Ceccato-Antonini, S.R., 2011. Bioprospection of yeasts as biocontrol agents against phytopathogenic molds. Braz. Arch. Biol. Technol. $54,1-5$.

Santos, A., Sanchez, A., Marquina, D., 2004. Yeasts as biological agents to control Botrytis cinerea. Microbiol. Res. 159, 331-338.

Shaner, G., Finney, R.E., 1977. The effects of nitrogen fertilization on the expression of slowmildwing in Knox wheat. Phytopathology 67, 1051-1055.

Sharma, R.R., Singh, D., Singh, R., 2009. Biological control of postharvest diseases of fruits and vegetables by microbial antagonists: a review. Biol. Control 50, 205-221.

Spadaro, D., Droby, S., 2016. Development of biocontrol products for postharvest diseases of fruit: the importance of elucidating the mechanisms of action of yeast antagonists.
Trends Food Sci. Technol. 47, 39-49. http://dx.doi.org/10.1016/j.tifs.2015.11.003. Strano, M.C., Altieri, G., Admane, N., Genovese, F., Di Renzo, G.C., 2017. Advance in citrus postharvest management: diseases, cold storage and quality evaluation. In: Citrus Pathology. InTech.

Sun, X., Ruan, R., Lin, L., Zhu, C., Zhang, T., Wang, M., Li, H., Yu, D., 2013. Genomewide investigation into DNA elements and $\mathrm{ABC}$ transporters involved in imazalil resistance in Penicillium digitatum. FEMS Microbiol. Lett. 348, 11-18.

Tao, N., Jia, N., Zhou, H., 2014. Anti-fungal activity of Citrus reticulata Blanco essential oil against Penicillium italicum and Penicillium digitatum. Food Chem. 153, 265-271.

Thompson, J.D., Higgins, D.G., Gibson, T.J., Clustal, W., 1994. Improving the sensitivity of progressive multiple sequence alignment through sequence weighting, positionspecific gap penalties and weight matrix choice. Nucleic Acids Res. 22, 4673-4680.

Tian, J., Ban, X., Zeng, H., Huang, B., He, J., et al., 2011. In vitro and in vivo activity of essential oil from dill (Anethum graveolens L.) against fungal spoilage of cherry tomatoes. Food Control 22, 1992-1999.

Usall, J., Smilanick, J., Palou, L., Denis-Arrue, N., Teixidó, N., Torres, R., Viñas, I., 2008. Preventive and curative activity of combined treatments of sodium carbonates and Pantoea agglomerans CPA-2 to control postharvest green mold of citrus fruit. Post. Biol. Technol. 50, 1-7.

Walker, G.M., Mcleod, A.H., Hodgson, V.J., 1995. Interactions between killer yeasts and pathogenic fungi. FEMS Microbiol. Lett. 127, 213-222.

Wang, X., Li, G., Jiang, D., Huang, H.C., 2009. Screening of plant epiphytic yeasts for biocontrol of bacterial fruit blotch (Acidovorax avenae subsp. citrulli) of hami melon. Biol. Control 50, 164-171.

Weiler, F., Schmitt, M.J., 2003. Zygocin, a secreted antifungal toxin of the yeast Zygosaccharomyces bailii, and its effect on sensitive fungal cells. FEMS Yeast Res. 3, 69-76.

White, T.J., Bruns, T., Lee, S., Taylor, J., Gelfand, D.H., 1994. Amplification and direct sequencing of fungal ribosomal RNA genes for phylogenetics. In: Innis, M., Sninsky, J.J., White, T.J. (Eds.), PCR Protocols: A Guide to Methods and Applications. Academic Press, New York, pp. 315-321.

Zhang, H.Y., Zheng, X., Xi, Y.F., 2005. Biological control of postharvest blue mould of orange by Cryptococcus laurentii (Kufferath) Skinner. BioControl 50, 331-342.

Zhou, Y., Deng, L., Zeng, K., 2014. Enhancement of biocontrol efficacy of Pichia membranaefaciens by hot water treatment in postharvest diseases of citrus fruit. Crop Prot. 63, 89-96 